\title{
THE EFFECT OF CLIMATE CHANGE ON OFFICE BUILDING ENERGY CONSUMPTION IN JAPAN \\ Shibuya, $\mathbf{T}^{1}$, Croxford $\mathrm{B}^{2}$
}

\section{1}

Bartlett School of Environment, Energy and Resources

University College London

London, WC1E 6BT

toshihiko.shibuya@chcsys.net

2 Corresponding Author

Ben Croxford

Bartlett School of Environment, Energy and Resources

University College London

London, WC1E 6BT

b.croxford@ucl.ac.uk

\section{Keywords}

climate change, energy consumption, cooling/heating loads, $\mathrm{CO} 2$ emissions reduction, thermal analysis simulations, nuclear power generation,

\section{ABSTRACT}

Global climate change is making the mild Japanese climate significantly warmer, which is expected to have a substantial impact on building energy consumption. The potential impacts of climate change on the cooling and heating loads for offices are also investigated by means of thermal analysis simulations at three sites over three periods; 1981-2000, 2031-2050, and 2081-2100.

This study reveals that under the IPCC's A2 carbon emission scenario, substantial reductions of energy consumption are expected if the full measures reviewed here are implemented. These rates differ in each location and each period due to regional climate characteristics and climate change. $\mathrm{CO} 2$ emissions reduction targets will depend on future electricity conversion factors which could worsen due to revisions of the national energy plan triggered by the Fukushima nuclear accident. 
Japan still has a vast quantity of energy inefficient old offices (pre-1981). With more specific and up-to-date technologies than those reviewed here, even greater energy reductions could be completed. A brief economic analysis suggests that these measures could be competitive with nuclear power generation.

Overall, office buildings in Japan have enormous potential to reduce energy requirements and related $\mathrm{CO} 2$ emissions without resorting to nuclear power generation.

\section{INTRODUCTION}

Recently, interest in sustainability has grown exponentially in conjunction with compelling scientific evidence on the contributions of anthropogenic factors to global climate. Global climate change is making the mild Japanese climate significantly warmer, which is expected to have a substantial impact on energy consumption and related CO2 emissions (1). The Japanese government ratified the Kyoto Protocol in 2002 and has been attempting to create a low carbon society. As a result, in 2008 the Prime Minister of Japan released a new vision entitled "Towards a Low-Carbon Society" which includes setting up a long-term target to reduce 60-80\% CO2 emissions by 2050 from the 1990 level (2).

In Japan in recent years, energy consumption in the commercial sector has increased, especially in office buildings for heating and cooling $(3,4)$. Thus, promoting a reduction of heating and cooling demand and related $\mathrm{CO} 2$ emissions in offices is a major task for attaining the national target. It is also important to consider the influence of expected climate change on space heating and cooling. Additionally, Japan's energy policy is facing a major turning point. The Great East Japan Earthquake and accident at the Fukushima Daiichi Nuclear Power Station in 2011, laid bare the risks associated with nuclear power and exposed the vulnerabilities of and strains on Japan's energy supply system. The revisions of the national energy plan triggered by the Fukushima nuclear accident will reduce dependence on nuclear power in the future, in 2011 around $30 \%$ of electricity was generated by nuclear power (3). Discussions on Japan's future energy policy place priority on the supply side (5). We suggest it is also very important to consider the demand side, and in particular attempts to reduce energy consumption in office buildings.

There have been a number of studies on the impact of climate change on energy use in office buildings worldwide. Additionally, work has started in many countries to develop weather files suitable for building energy demand simulations that take into consideration future climate change scenarios. While some researchers have studied the effects of global warming on total energy consumption in office buildings, few have shown the most effective measures and their impact to get the target reduction of $\mathrm{CO} 2$ in future Japanese offices. In Japan, three hourly weather datasets representing each of the periods; current, 2040's and 2090's (1981-2000) have 
been constructed by Soga and Akasaka (6) and these were utilized in this study. The future weather datasets were based on the A2 climate change scenario of the IPCC, Kubota and Soga (7). In this study, these latest current and future weather data were utilized, which leads to more reliable calculation in future cooling/heating loads.

This paper presents the results of a computational study on the energy consumption and related $\mathrm{CO} 2$ emissions for heating and cooling of offices in several sites throughout Japan, currently and in the future. The aim of the paper is to develop a detailed analysis of changes in building space cooling and heating due to climate change, and to propose effective measures such as refurbishment technologies that could reduce the $\mathrm{CO} 2$ emissions of office buildings in Japan by $60-80 \%$ by the year 2050 .

\section{METHODOLOGY}

The study simulated an office with typical construction, heat gains, and operational patterns with Thermal Analysis Software (TAS) (8). The Japanese weather files mentioned previously were utilized. Several strategies for reducing heating/cooling demand are described and analysed.

\subsection{Weather files}

\subsubsection{Reference weather year}

Weather data in Japan is acquired by the Automated Meteorological Data Acquisition System (AMeDAS) of the Japan Meteorological Agency (JMA). Weather data for the current period developed as Expanded AMeDAS (EA weather data) (9). EA weather data are hourly data obtained from 842 stations throughout Japan over 20 years (1981-2000). EA weather data was reformatted considering not only equality of the monthly mean of each weather parameter but also equality of the frequency of each day's value (6). As a result, a reference weather year (Standard EA weather data) was constructed.

\subsubsection{Future weather filles}

JMA (10) produced two types of future weather data for Japan: 2031-2050 (2040s) and 2081-2100 (2090s). There are 46 variables including; daily air temperature (mean, maximum, and minimum), humidity ratio, wind direction and speed, degree of cloudiness (upper-air, middle-air, and lower-air observation), precipitation, and more for each of 11,881 nodes whose $20 \mathrm{~km}$ apart. These data based on AMeDAS data, were made by a specific software named Regional Climate Model 20 (RCM20) developed by JMA. Scenario A2 of the IPCC was adopted through a series of simulations. However, there are no data of horizontal global solar radiation and 
atmospheric radiation, which are essential for building energy calculations. Additionally, these data are daily, not hourly.

Soga (11) developed two types of hourly future weather data (2040s, 2090s) available for building energy calculations. He chose 833 nodes from which to use as base data, which are located nearest to the sites observed by JMA (AMeDAS). He calculated horizontal global solar radiation and atmospheric radiation using statistical functions. As a result, the new weather data were considered to be predicted values of air temperature, absolute humidity, solar radiation quantity, and wind direction and velocity.

\subsubsection{Site selection}

The Japanese standards about commercial buildings reference several climate zones by criteria based on their topographical characteristics. The largest city in each climate zone of specification criteria was selected as the subject of the simulation's research. As a result, Sapporo (cold zone), Tokyo (ordinary zone), and Naha (tropical zone) were selected (Figure 1 and Table 1). Figure 2 and Table 2 show that in each site air temperature increases at each period relative to the previous period. For relative humidity, no clear change was indicated between the periods.

Table 1: Latitude and Longitude of the three locations selected in Japan

\begin{tabular}{|c|c|c|}
\hline City & Latitude (deg.N) & Longitude (deg.E) \\
\hline Sapporo & 43.06 & 141.35 \\
\hline Tokyo & 35.68 & 139.77 \\
\hline Naha & 26.20 & 127.69 \\
\hline
\end{tabular}




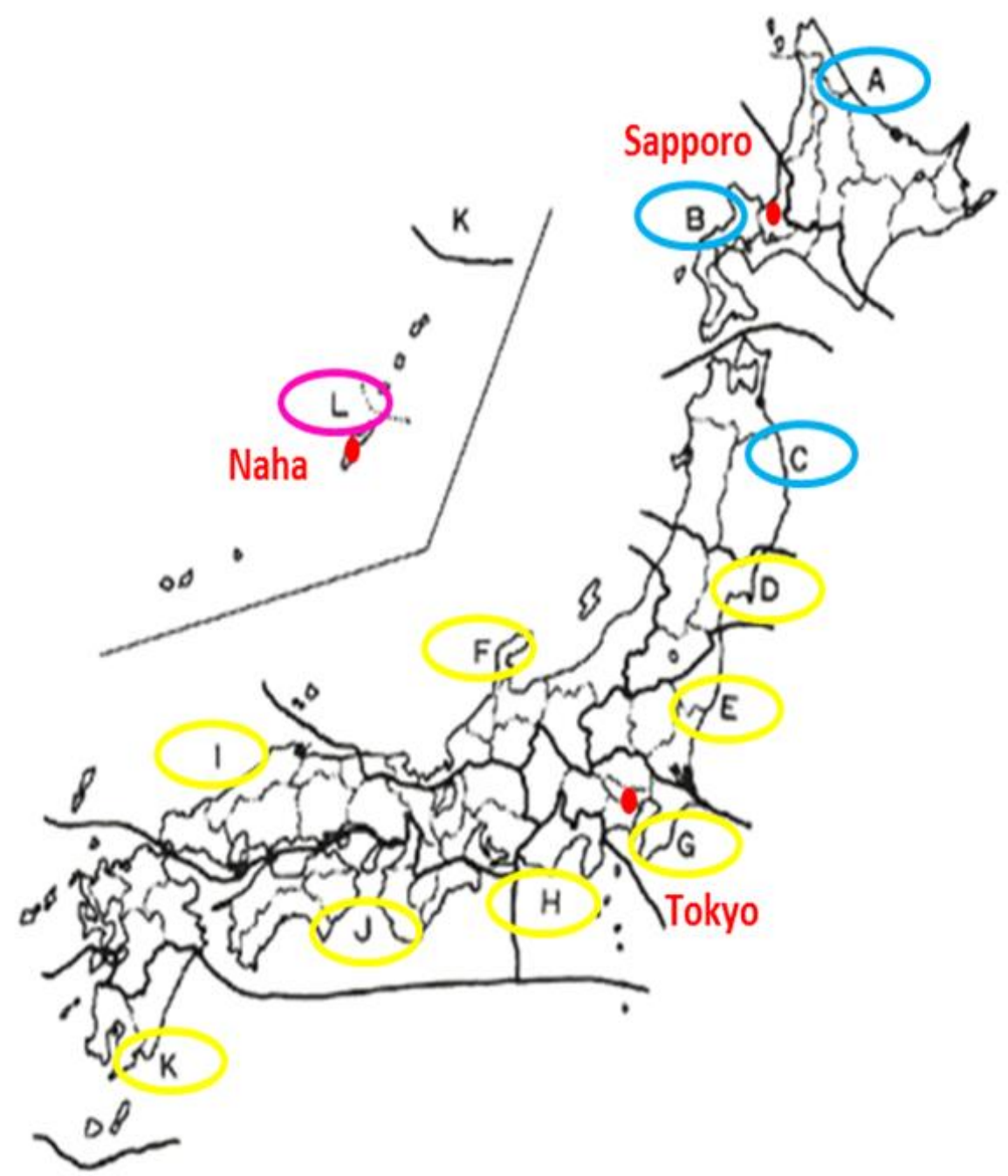

Figure 1: Location of the three locations selected in Japan

Blue circle: cold zone, Yellow circle: ordinary zone, Red circle: tropical zone

Table 2: Yearly external air temperature values.

\begin{tabular}{|c|c|c|c|c|c|c|c|c|c|}
\hline \multirow{2}{*}{ Air temperature $\left({ }^{\circ} \mathrm{C}\right)$} & \multicolumn{3}{|c|}{ Sapporo } & \multicolumn{3}{|l|}{ Tokyo } & \multicolumn{3}{|l|}{ Naha } \\
\hline & 1990s & $2040 s$ & 2090s & 1990s & 2040s & 2090s & 1990s & 2040s & 2090s \\
\hline Mean & 8.9 & 10.7 & 11.8 & 16.2 & 18.3 & 18.9 & 23.0 & 24.1 & 25.2 \\
\hline Median & 9.3 & 11.5 & 12.8 & 16.6 & 18.8 & 19.5 & 23.5 & 24.6 & 25.6 \\
\hline Minimum & -12.4 & -11.0 & -8.9 & -0.2 & 2.4 & 2.5 & 11.1 & 11.6 & 13.7 \\
\hline Maximum & 34.8 & 34.1 & 35.8 & 35.2 & 35.3 & 37.3 & 32.6 & 34.0 & 34.6 \\
\hline Standard Deviation & 9.6 & 9.6 & 9.3 & 8.0 & 7.0 & 7.4 & 4.7 & 4.8 & 4.6 \\
\hline
\end{tabular}




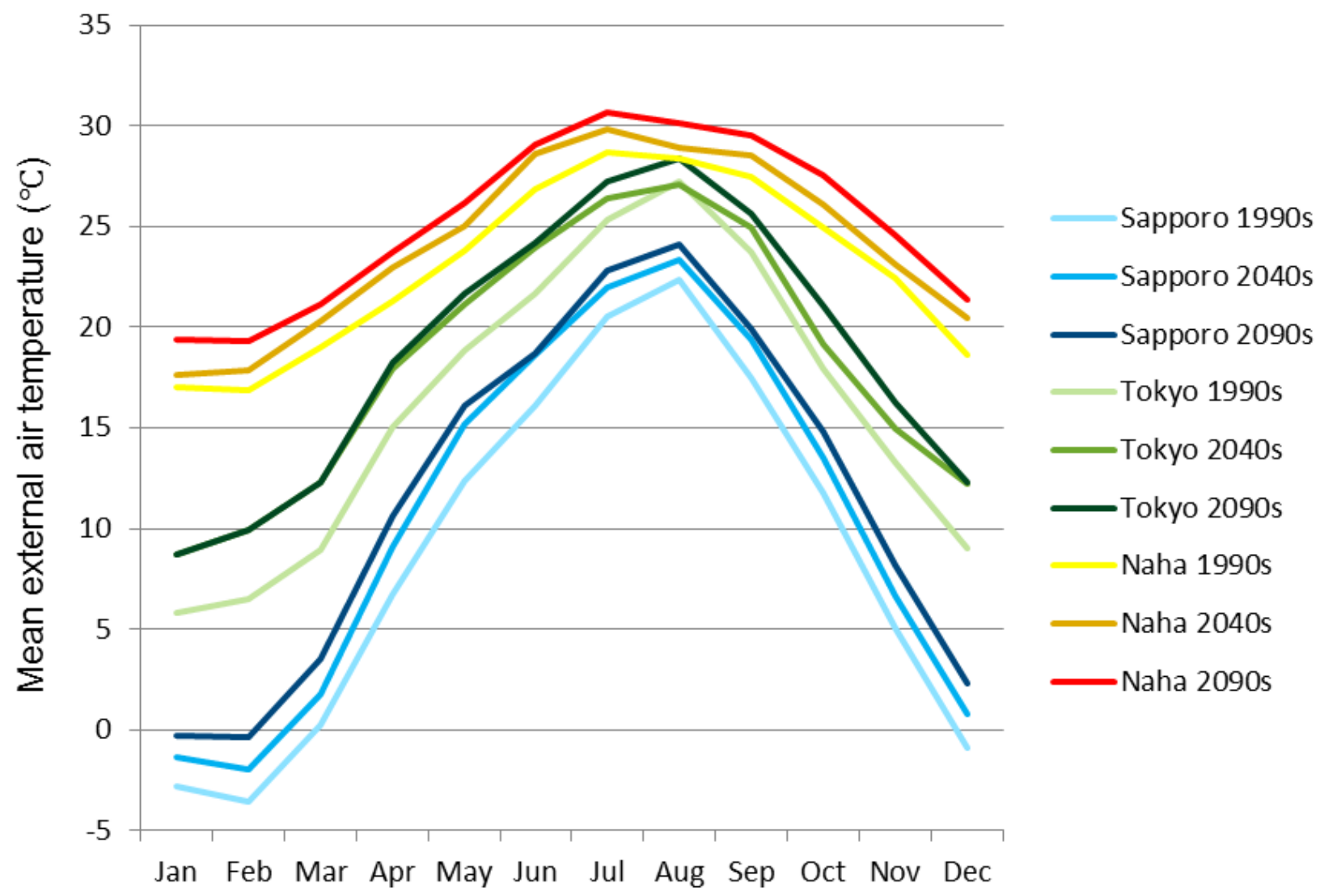

Figure 2: Monthly mean external air temperature

\subsection{Office Building Model}

\subsubsection{Base model}

A geometrical model was defined; an eight-storey building with dimensions of $33.6 \mathrm{~m}$ wide, $24.6 \mathrm{~m}$ deep, and $3.6 \mathrm{~m}$ high (3.8 $\mathrm{m}$ high at ground floor) based on previous models of office buildings widely used for simulations in Japan (12). The office building oriented with the longer sides facing north-south. Around onethird of the office building stock in the chief cities of Japan dates from before 1981 (13), thus, this model is considered to be representative of a typical, air-conditioned office in Japanese cities in the 1990s, with a total floor area of 6,612 m2, of which the air-conditioned floor area is 5,250 $\mathrm{m} 2$ (east and west office zones and EV hall zone, Figure 3). 

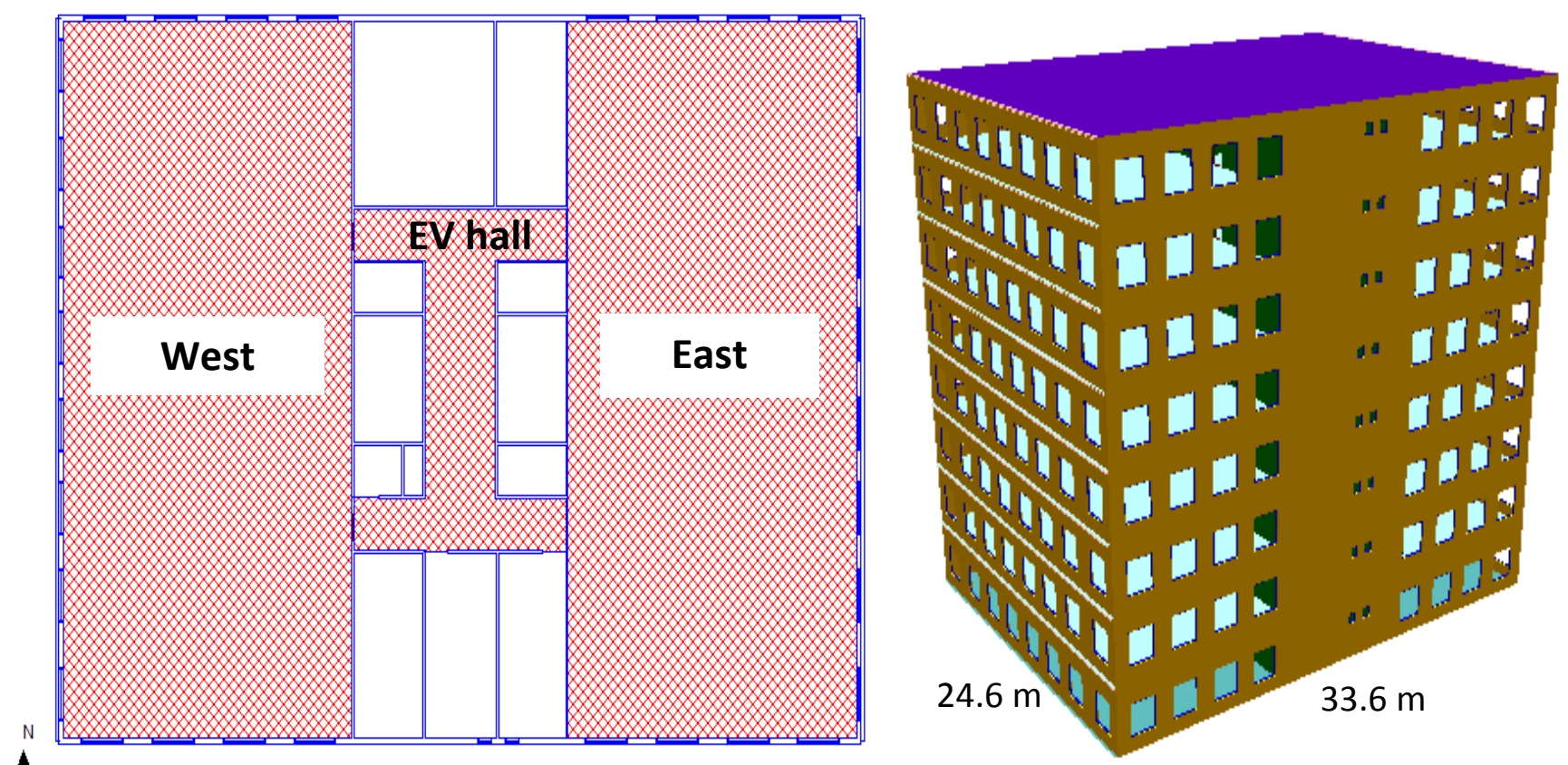

\section{Red-coloured areas are the air-conditioned areas, while blank areas are unconditioned utility spaces and toilets.}

Figure 3: Office building model and zoning for typical 1990s type buildings (a representative floor plan and outward)

Consequently, the shape and orientation were set as fixed parameters although they influence the total energy use in a building and the solar energy that it receives (14). With this layout, in winter maximum solar gains can be achieved, while in summer, efficient shading should be considered. Additionally, this orientation can provide maximum daylight but also the related unpleasant glare. Thus blinds should be utilized effectively, especially on south façades. A typical wall construction was used and windows were single glazed with $30 \%$ glazing ratio in office zones. The building has no insulation and single skin block construction type walls and thus can be considered to be a lightweight building.

The occupant density in office zones and EV hall zones are estimated to be 0.2 and 0.03 person $/ \mathrm{m} 2$, respectively (12) (EV = elevator, or lift). For the office area of the base floor for example, the size of one office area is $12.3 \times 24.6 \times 3.6$, for area $=302.6 \mathrm{~m} 2$ and volume $=1,089.3 \mathrm{~m} 3$. For the given occupant density, $302.6 \times 0.2 \fallingdotseq 60$ people, the fresh air requirement is $600 \mathrm{~L} / \mathrm{s}$, hence the air change rate is $600 \times 3.6 / 1089.3 \fallingdotseq 2 \mathrm{ach}$. The air change rate for EV hall zones was calculated to be 0.3 in the same way. Meanwhile, air infiltration is hard to estimate because this parameter depends on the building and weather conditions. Therefore an air change rate of 2.0 ach 
(office zones) and 0.3 ach (EV hall zone), and an assumed infiltration rate of 0.25 ach, were fixed (Table 3).

Note typical 1990s type office buildings in Japan had no heat recovery (12).

The internal heat gains and the target temperature and relative humidity were defined using data from reference (12, Appendix 1); note that it was typical to work saturday mornings in 1990, but current and future trends mean that this is now an outdated practice and a 5 day working week is normal. (Appendix 2).

Table 3: Internal conditions for the base model for typical 1990s type office buildings, based on (12).

\begin{tabular}{|c|c|c|c|c|c|c|c|c|c|c|c|c|}
\hline & & & & & liahtina & Occupants & & & & & Equipment & \\
\hline & & $\begin{array}{c}\text { Floor area } \\
\left(\mathrm{m}^{3}\right)\end{array}$ & $\begin{array}{l}\text { Infiltration } \\
\text { (ach) }\end{array}$ & $\begin{array}{c}\text { Ventilation } \\
\text { (ach) }\end{array}$ & heat gain & Density & Sensible $\mathrm{h}$ & eat gain & Latent he & at gain & Sensible & Latent \\
\hline & & & & & & $\left(\right.$ person $\left./ \mathrm{m}^{2}\right)$ & (W/person) & $\left(\mathrm{W} / \mathrm{m}^{2}\right)$ & (W/person) & $\left(\mathrm{W} / \mathrm{m}^{2}\right)$ & $\left(\mathrm{W} / \mathrm{m}^{2}\right)$ & $\left(\mathrm{W} / \mathrm{m}^{2}\right)$ \\
\hline & east & 2401.0 & 0.25 & 2.00 & 20.0 & 0.20 & 75.0 & 15.0 & 55.0 & 11.0 & 20.0 & 0.0 \\
\hline & west & 2401.0 & 0.25 & 2.00 & 20.0 & 0.20 & 75.0 & 15.0 & 55.0 & 11.0 & 20.0 & 0.0 \\
\hline EV & & 448.2 & 0.25 & 0.30 & 10.0 & 0.03 & 75.0 & 2.3 & 55.0 & 1.7 & 0.0 & 0.0 \\
\hline
\end{tabular}

\subsubsection{Improved model}

A series of simulations with different measures or improvements applied were carried out. In the following figures, the improved factors are shown in red ink.

(1) Lighting and equipment improvements (Reducing internal heat gains)

Recently the efficiency of office appliances has improved significantly by technological innovations, and efficiency improvements in lighting of $40 \%$ and equipment of much more than $40 \%$, can be estimated (4). As a result, the internal heat gains for the improved model were reduced (Table 4). In future decades further improvements are likely but not considered here. 
Table 4: Internal heat gains of lighting and equipment (4)

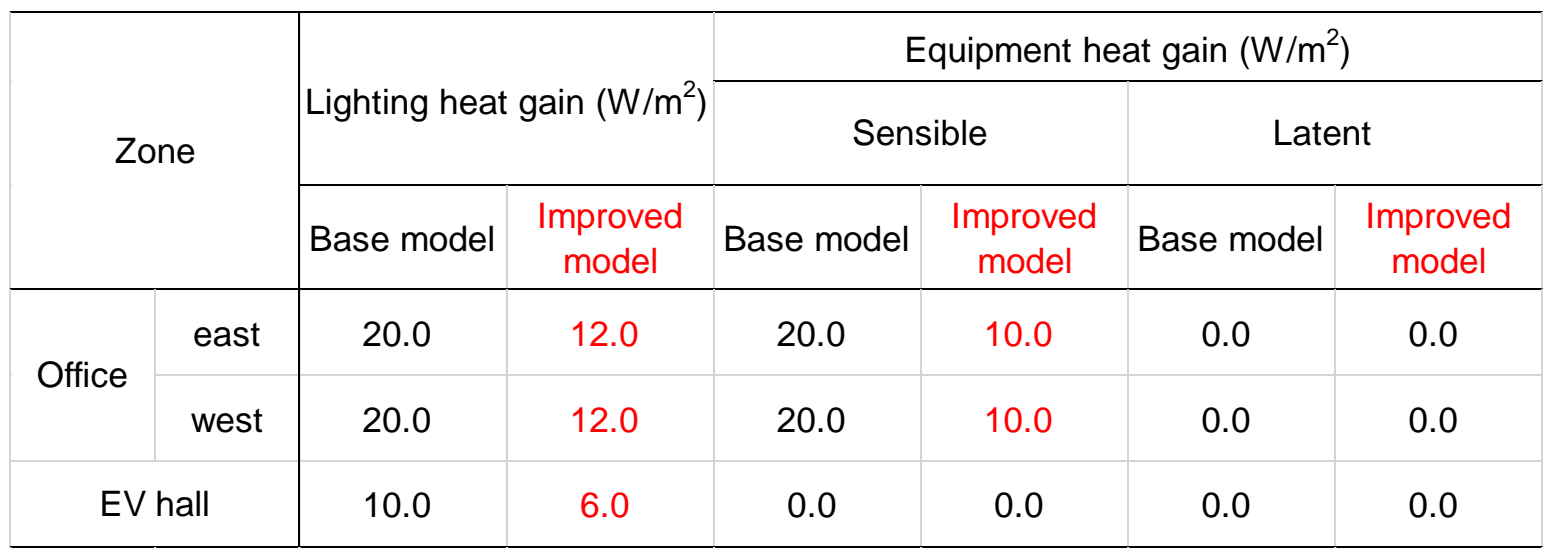

(2) Relaxation of temperature set points

A voluntary action to relax the set temperature of air conditioners has been carried out recently in Japan. The plan recommends setting the temperature higher in the summer and lower in the winter compared to the usual settings (15). In improved models, the target temperature and relative humidity in each season are relaxed by 1-2 ${ }^{\circ} \mathrm{C}$ and $5 \%$, respectively (Table 5).

Table 5: Target temperature and relative humidity

\begin{tabular}{|c|c|c|c|c|c|}
\hline \multirow{2}{*}{\multicolumn{2}{|c|}{ Season }} & \multicolumn{2}{|c|}{ Temperature $\left({ }^{\circ} \mathrm{C}\right)$} & \multicolumn{2}{|c|}{$\mathrm{RH}(\%)$} \\
\hline & & Base model & Improved model & Base model & Improved model \\
\hline Winter & (Jan-Apr + Dec) & $21-24$ & $20-24$ & $40-60$ & $40-65$ \\
\hline Summer & (Jun-Sep) & $23-26$ & $23-28$ & $45-65$ & $45-70$ \\
\hline Mid season & (Other) & $21-25$ & $20-26$ & $40-65$ & $40-70$ \\
\hline
\end{tabular}

(3) Building envelop improvement (Improvement of glazing, walls and the roof)

Window glazing is one of the weakest thermal control factors in building interiors, single glazing (with a high Uvalue was standard for pre-1981 offices in Japan (12). Since there were differences between the climates of the three locations selected in this study, both double glazed windows with low-e coating and double clear glazing were examined as the improved models.

Additionally, in order to control heat loss in buildings and reduce heating and cooling demand, adding to the thickness of the insulation within external walls and the roof should be considered. In this study, insulation that 
had been doubled $(50 \mathrm{~mm})$ and quadrupled $(100 \mathrm{~mm})$ was examined for the thickness of insulation, $25 \mathrm{~mm}$ insulation is the standard for pre-1981 offices in Japan (12).

Overall, a combination of double glazing with low-e coating and quadrupled insulation, and that of double clear glazing and doubled insulation were simulated as the two improved models. Comparisons of the thermal transmittance (U-value) of each element between the base model and the two improved models are shown in Table 6 . The glazing ratio and blinds were not changed from the base model.

Table 6: Building elements

\begin{tabular}{|c|c|c|c|c|}
\hline \multirow{2}{*}{ Model } & \multirow{2}{*}{ Description } & \multicolumn{3}{|c|}{ U-value $\left(\mathrm{W} / \mathrm{m}^{2} / \mathrm{K}\right)$} \\
\hline & & Window & External wall & Roof \\
\hline Base model & $\begin{array}{l}\text { single clear glazing with blind, } \\
\text { polystyrene insulation }(25 \mathrm{~mm}) \text { on external walls and } \\
\text { the roof }\end{array}$ & 5.7 & 0.6 & 0.4 \\
\hline Improved model 1 & $\begin{array}{l}\text { double clear glazing with blind, } \\
\text { doubled insulation }(50 \mathrm{~mm}) \text { on external walls and the } \\
\text { roof }\end{array}$ & 2.0 & 0.4 & 0.3 \\
\hline Improved model 2 & $\begin{array}{l}\text { double glazing with low-e coating with blind, } \\
\text { quadrupled insulation }(100 \mathrm{~mm}) \text { on external walls and } \\
\text { the roof }\end{array}$ & 1.5 & 0.2 & 0.2 \\
\hline
\end{tabular}

(4) Overhangs

Shading devices on building façades control the amount of solar radiation received by the building, and can therefore reduce the energy consumption at certain times of the year, though they are counter-productive at other times $(16,17)$. For example, in the summer they could decrease the cooling loads by increasing the solar protection, while increasing the heating loads in the winter. Past studies have proposed that they should be designed so that their position can be adapted to the season of the year (18). Thus in this study, the monthly cooling/heating loads were examined by using projecting horizontal overhangs that can be folded back or removed. They were set on both east and west facades and their material was assumed to be aluminium, which is typical in Japan (Table 7). 
Table 7: Overhangs

\begin{tabular}{|c|c|c|c|}
\hline Shaded surface & Depth & $\begin{array}{c}\text { Vertical offset from top } \\
\text { edge of shaded surface }\end{array}$ & Transmittance \\
\hline $\begin{array}{c}\text { Windows on } \\
\text { east/west façades }\end{array}$ & $1.0 \mathrm{~m}$ & $0.2 \mathrm{~m}$ & 0.92 \\
\hline
\end{tabular}

\section{(5) Night cooling}

Night cooling is an effective passive strategy, especially in non-residential buildings with a high cooling demand and with no night occupation. This strategy helps to decrease demand peaks and operation periods of airconditioning equipment (16). However, it is important to control this ventilation strategy appropriately in terms of avoiding over-cooling and optimizing heat absorption. In this study, night cooling was used only when the internal temperature exceeded $18^{\circ} \mathrm{C}$ and only when the external temperature exceeded $12^{\circ} \mathrm{C}$. Night cooling was operated only when both conditions were met at the same time. Night cooling was planned to begin at 22.00 PM and continue until 7.00 AM.

One important consideration in the parametric analysis is the thermal mass of the construction (19). A heavy weight version of the base model was tested, where the material of internal floors were changed. (Table 8). As a result, the effect of night cooling for heating/cooling loads reduction was examined by using two models. 
Table 8: Construction properties for thermal response factor

Base model (lightweight, $f r=2.38$ )

\begin{tabular}{|l|c|c|c|c|c|}
\hline & Area $\left(\mathrm{m}^{2}\right)$ & $\mathrm{U}\left(\mathrm{W} / \mathrm{m}^{2} \mathrm{~K}\right)$ & $\mathrm{Y}\left(\mathrm{W} / \mathrm{m}^{2} \mathrm{~K}\right)$ & $\mathrm{AU}$ & $\mathrm{AY}$ \\
\hline External wall & 3375.60 & 0.62 & 0.43 & 2092.87 & 1451.51 \\
\hline Internal wall & 815.84 & & 2.16 & & 1762.21 \\
\hline Internal floor & 5785.92 & & 0.72 & & 4165.86 \\
\hline Roof & 826.56 & 0.44 & 0.36 & 363.69 & 297.56 \\
\hline Ground floor & 826.56 & & 0.26 & & 214.91 \\
\hline Sum & & & & 2456.56 & 7892.05 \\
\hline & & & & \\
\hline Improved model & heavyweight, thermal mass, fr=4.11) & & \\
\hline & Area $\left(\mathrm{m}^{2}\right)$ & $\mathrm{U}\left(\mathrm{W} / \mathrm{m}^{2} \mathrm{~K}\right)$ & $\mathrm{Y}\left(\mathrm{W} / \mathrm{m}^{2} \mathrm{~K}\right)$ & $\mathrm{AU}$ & $\mathrm{AY}$ \\
\hline External wall & 3375.60 & 0.62 & 0.43 & 2092.87 & 1451.51 \\
\hline Internal wall & 815.84 & & 2.16 & & 1762.21 \\
\hline Internal floor & 5785.92 & & 1.10 & & 6364.51 \\
\hline Roof & 826.56 & 0.44 & 0.36 & 363.69 & 297.56 \\
\hline Ground floor & 826.56 & & 0.26 & & 214.91 \\
\hline Sum & & & & 2456.56 & 10090.70 \\
\hline
\end{tabular}

\section{RESULTS}

The results from the simulations are presented.

\subsection{Results of Model of Typical Offices}

Table 9 and Figure 4 indicate that the total heating/cooling loads in all three climate regions of Japan will increase with global warming and increase rates are different depending on location. Naha has the highest cooling load, and no heating load. Tokyo can be seen as being cooling dominated, and the cooling load in both significantly increases with climate change. Total heating/cooling loads in Tokyo and Naha will rise, while in Sapporo total consumption will stay almost constant since the decrease in heating loads will balance out the increase in cooling loads. From the 2040s onward, cooling loads are projected to exceed heating loads. The results found by the authors are broadly in line with those found by other researchers $(20,21)$, in this paper we focus on the comparison across climate zones and over time and consider relative changes between these 
scenarios which is an appropriate use for this office model, this building simulation model and the scenarios investigated.

Table 9: Heating/cooling loads of model of typical offices and percentage change compared to the 1990s

\begin{tabular}{|c|c|c|c|c|c|}
\hline & \multicolumn{3}{|c|}{ Air-conditioning loads (kWh/m²/year) } & \multirow{2}{*}{$\begin{array}{l}\text { Percentage change } \\
\text { compared to the } 1990 \mathrm{~s}\end{array}$} \\
\hline & & Heating loads & Cooling loads & Total loads & \\
\hline \multirow{3}{*}{ Sapporo } & 1990s & 38.4 & 34.9 & 73.3 & - \\
\hline & $2040 s$ & 30.2 & 45.3 & 75.5 & $3.0 \%$ \\
\hline & $2090 s$ & 23.8 & 51.2 & 75.0 & $2.3 \%$ \\
\hline \multirow{3}{*}{ Tokyo } & 1990s & 4.0 & 73.1 & 77.1 & - \\
\hline & $2040 s$ & 1.1 & 87.7 & 88.8 & $15.2 \%$ \\
\hline & $2090 s$ & 0.9 & 97.1 & 98.1 & $27.2 \%$ \\
\hline \multirow{3}{*}{ Naha } & $1990 \mathrm{~s}$ & 0.0 & 134.5 & 134.5 & - \\
\hline & $2040 s$ & 0.0 & 148.2 & 148.2 & $10.2 \%$ \\
\hline & $2090 s$ & 0.0 & 161.1 & 161.1 & $19.8 \%$ \\
\hline
\end{tabular}

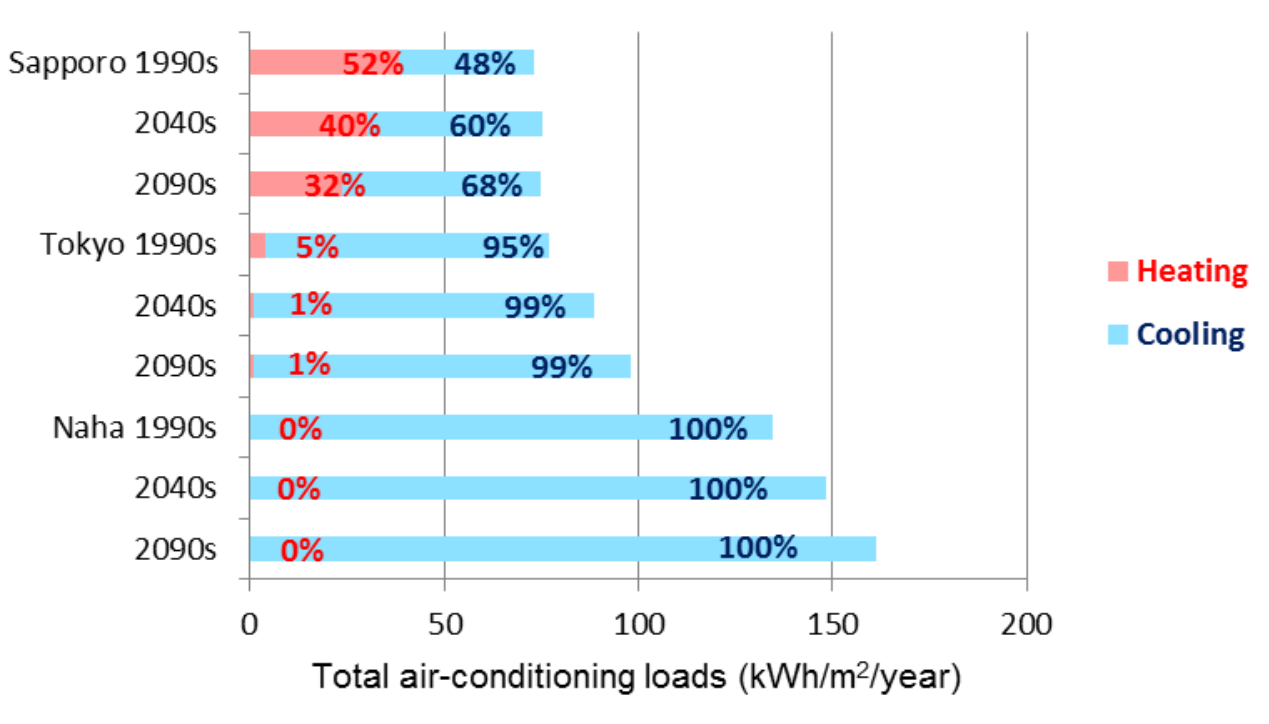

Figure 4: Heating/cooling loads of model of typical offices 


\subsection{Results of Models of Upgraded Offices}

Strategies to reduce energy consumption are tested both individually and cumulatively for each location and each time period.

\subsubsection{Effects of each strategy}

Figure 5 shows the potential for heating/cooling load reductions by each energy-saving measure introduced for each location and each time period. Tokyo and Naha have similar patterns as both are cooling dominated, while Sapporo is heating dominated and set point temperatures are the key variable.

Night cooling and improved glazing/insulation could also decrease the heating/cooling loads largely both now and in the future. The reduction rates would be constant in the future. Improved lighting/equipment would have a larger reduction rates in the future than the present. It is important to note that as in all locations and all periods a lower U-value would bring lower energy use in this study, a combination of double glazing with low-e coating and quadrupled insulation was selected for the model of upgraded offices. It is also important to note that in all locations and all periods the model of typical offices (lightweight building) with night cooling could reduce more of the heating/cooling loads than a heavyweight building with night cooling. Additionally, heavyweight materials are characterised by having higher embodied energy. Thus, in this study additions of thermal mass were not adopted.

In Tokyo and Naha improved lighting and equipment is the key variable for reducing air-conditioning loads. Additionally, only this measure is projected to decrease total heating/cooling loads both in the 2040s and 2090s. As the climate warms the effects of night cooling are less beneficial.

In all locations, overhangs provide the smallest cooling load reduction. Simulation found that in every location and period there is no clear difference in the reduction rates between the west office zone and the east office zone. This suggests that there is no need to consider different measures for areas located on the east or the west side in the building model used, either now or in the future.

It is clear that the effect of each strategy for reducing the heating/cooling requirements fluctuates significantly due to the climate characteristic of each location both now and in the future. 


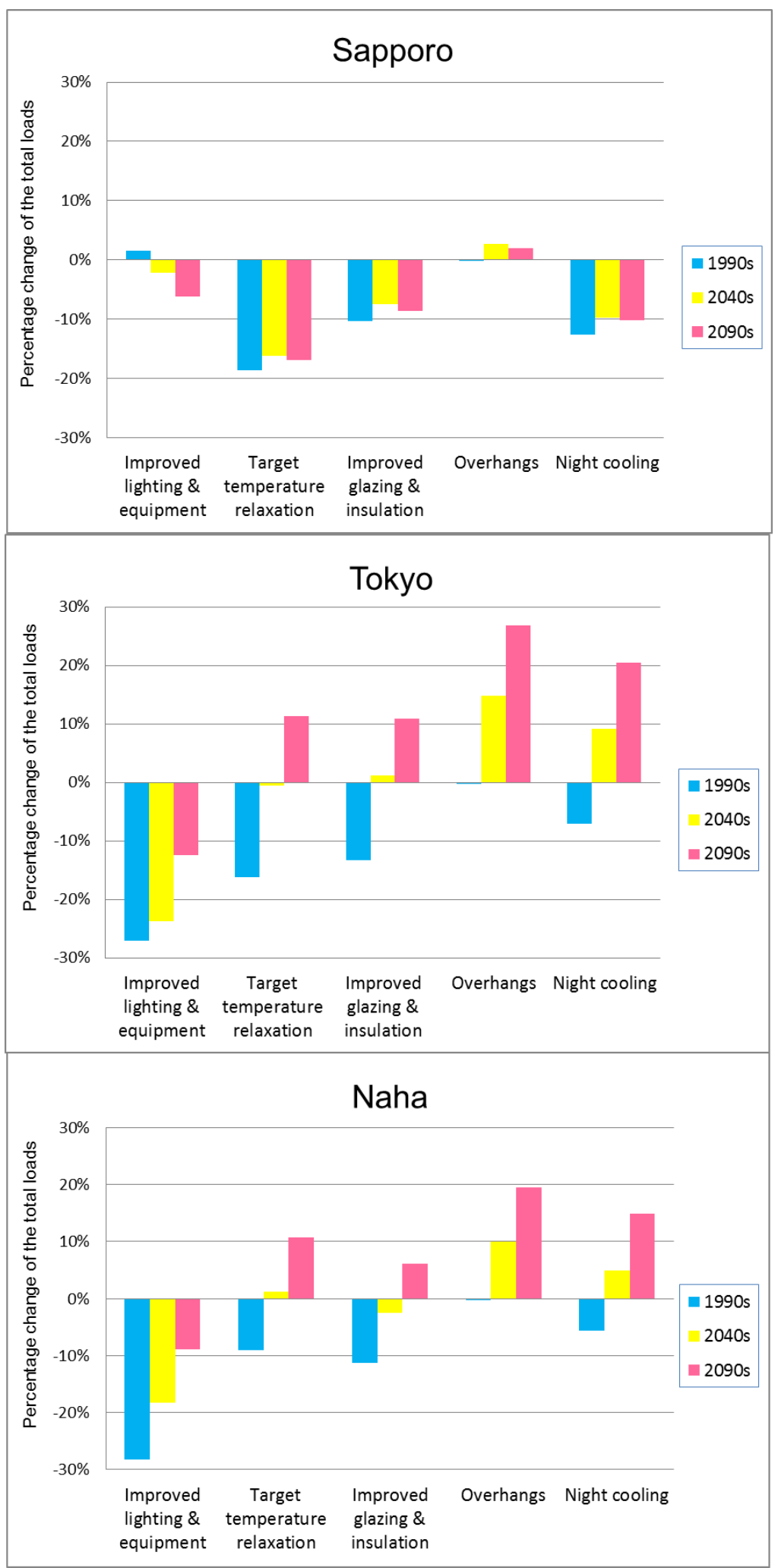

Figure 5: Percentage change of the total heating/cooling loads by each strategy compared to the 1990s model of typical offices 


\subsubsection{Cumulative effect of all the strategies}

The cumulatively improved model, in which all the effective strategies were introduced concurrently, can be seen in Table 10 and figure 6 . In all cases total consumption could be reduced from current levels despite the effects of climate change if the proposed measures were introduced as soon as possible.

Sapporo shows a continuous reduction over time, but Tokyo and Naha, increase total consumption with increasing climate change once measures have been implemented. In the future additional strategies should be considered to ensure total loads do not increase.

Table 10: Heating/cooling loads and percentage change of model of cumulatively upgraded offices and the 1990s model of typical offices

\begin{tabular}{|c|c|c|c|c|c|c|c|}
\hline & & \multicolumn{6}{|c|}{ Air-conditioning loads $\left(\mathrm{kWh} / \mathrm{m}^{2} /\right.$ year) } \\
\hline & & \multicolumn{3}{|c|}{$\begin{array}{l}\text { Cumulatively improved model } \\
\text { (Percentage change compared to the } 1990 \text { s base model) }\end{array}$} & \multicolumn{3}{|c|}{ 1990s base model } \\
\hline & & Heating loads & Cooling loads & Total loads & Heating loads & Cooling loads & Total loads \\
\hline \multirow[t]{3}{*}{ Sapporo } & 1990s & $40.8(+6.3 \%)$ & $7.0(-79.9 \%)$ & $47.9(-34.7 \%)$ & \multirow{3}{*}{38.43} & \multirow{3}{*}{34.91} & \multirow{3}{*}{73.34} \\
\hline & $2040 s$ & $33.2(-13.5 \%)$ & $11.3(-67.6 \%)$ & $44.5(-39.3 \%)$ & & & \\
\hline & $2090 s$ & $27.2(-29.3 \%)$ & $14.4(-58.9 \%)$ & $41.5(-43.4 \%)$ & & & \\
\hline \multirow[t]{3}{*}{ Tokyo } & $1990 s$ & $5.1(+27.8 \%)$ & $26.8(-63.4 \%)$ & $31.9(-58.6 \%)$ & \multirow{3}{*}{3.98} & \multirow{3}{*}{73.13} & \multirow{3}{*}{77.12} \\
\hline & $2040 s$ & $1.1(-71.9 \%)$ & $34.4(-53.0 \%)$ & $35.5(-53.9 \%)$ & & & \\
\hline & $2090 s$ & $1.0(-75.5 \%)$ & $41.4(-43.4 \%)$ & $42.4(-45.0 \%)$ & & & \\
\hline \multirow[t]{3}{*}{ Naha } & 1990s & - & $67.0(-50.2 \%)$ & $67.0(-50.2 \%)$ & \multirow{3}{*}{-} & \multirow{3}{*}{134.50} & \multirow{3}{*}{134.50} \\
\hline & $2040 s$ & - & $79.3(-41.0 \%)$ & $79.3(-41.0 \%)$ & & & \\
\hline & $2090 s$ & - & $91.1(-32.3 \%)$ & $91.1(-32.3 \%)$ & & & \\
\hline
\end{tabular}




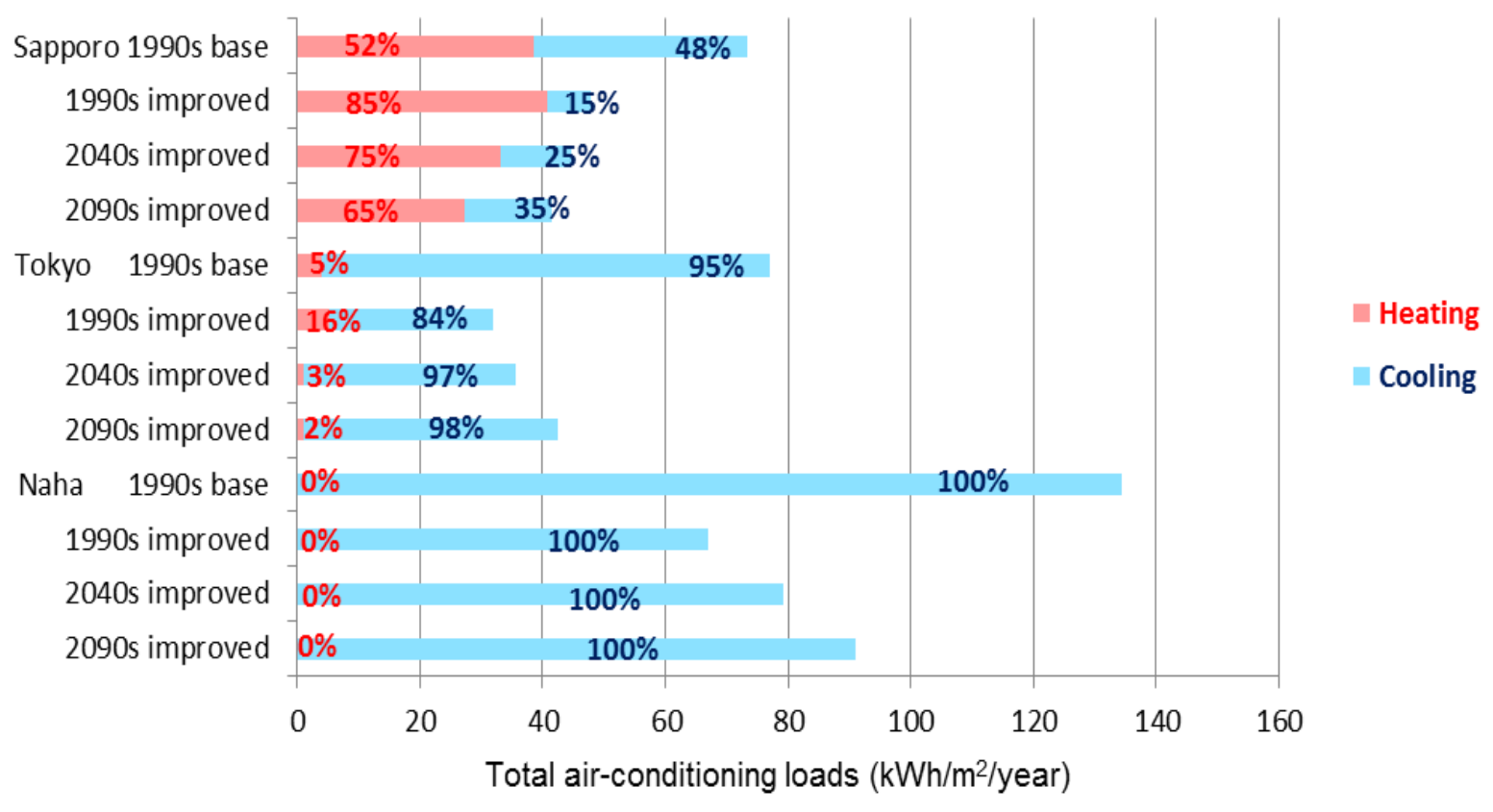

Figure 6: Heating/cooling load comparison between model of cumulatively upgraded offices and the 1990s model of typical offices

\subsection{Electric Energy Consumption and Carbon Dioxide Emissions}

In Japanese offices cooling and heating are usually provided by electricity two and a half times as much as by gas and other fuel (22). In this study, both heating and cooling using only electricity was assumed for the calculations.

A Coefficient of Performance (COP) of an all air distribution system (air-source heat pumps) was assumed to be 2.7 in the 1990s (22). On the other hand, 5.7 was used as the future value (Annual Performance Factor (APF)) since this value is the best target figure of manufacturers in 2015 (23). This means that in this study, future technological innovation after 2015 was ignored. Electric energy required for transporting cooling (fans, pumps, and controls) was also ignored.

An electricity conversion factor of $0.376 \mathrm{kgCO} 2 / \mathrm{kWh}$ was used for the calculations in the 1990s (24). Two future electricity conversion factors of $0.551 \mathrm{kgCO} 2 / \mathrm{kWh}$ and $0.689 \mathrm{kgCO} 2 / \mathrm{kWh}$ were estimated (25). The high estimate assumes $0 \%$ nuclear, the low estimate $20-22 \%$ nuclear power and that the reduction of nuclear power 
can be offset by other low-CO2-emitting energies such as wind. [Note: Japanese government made announce that nuclear power generation rate should be $20-22 \%$ in 2030, (April 2015).]

Table 11 shows that in all locations electricity consumption for air-conditioning can be reduced by around $70 \%$ in the future. This means that installing all the strategies introduced here could lead to meeting the national energy consumption reduction target, which is to reduce energy demand by $40 \%$ (relative to the 2000 value) in the commercial sector to achieve the proposed $70 \%$ CO2 emissions reductions by 2050 (2). However, Table 11 suggests that in all locations the related $\mathrm{CO} 2$ emissions cannot be reduced by $70 \%$ in the future even if electricity conversion factors remain unchanged $(0.551 \mathrm{kgCO} 2 / \mathrm{kWh})$. Additionally, there are clear differences between the reduction rates of each location.

Overall, in order to meet the national $\mathrm{CO} 2$ emissions reduction target, additional effective strategies for buildings that consider regional climate differences should be completed. Decarbonisation of the grid and further improvements of air-conditioning units are both still required.

Table 11: Electricity consumption for heating/cooling and reduction rates compared to the 1990s model of typical offices

\begin{tabular}{|l|l|c|c|c|}
\hline \multirow{2}{*}{} & \multicolumn{4}{|l}{$\begin{array}{l}\text { Electricity consumption for heating/cooling }\left(\mathrm{kWh} / \mathrm{m}^{2} / \text { year) and reduction rates compared to 1990s }\right. \\
\text { base model (\%) }\end{array}$} \\
\cline { 2 - 5 } & $\begin{array}{r}\text { 1990s base model } \\
\text { (COP 2.7) }\end{array}$ & $\begin{array}{c}\text { 1990s improved model } \\
\text { (COP 2.7) }\end{array}$ & $\begin{array}{c}\text { 2040s improved model } \\
\text { (APF 5.7) }\end{array}$ & $\begin{array}{c}\text { 2090s improved model } \\
\text { (APF 5.7) }\end{array}$ \\
\hline Sapporo & 27.2 & $17.7(-34.7 \%)$ & $7.8(-71.2 \%)$ & $7.3(-73.2 \%)$ \\
\hline Tokyo & 28.6 & $11.8(-58.6 \%)$ & $6.2(-78.2 \%)$ & $7.4(-74.0 \%)$ \\
\hline Naha & 49.8 & $24.8(-50.2 \%)$ & $13.9(-72.1 \%)$ & $16.0(-67.9 \%)$ \\
\hline
\end{tabular}


Table 12: CO2 emissions for heating/cooling and reduction rates compared to the 1990s model of typical offices

\begin{tabular}{|c|c|c|c|c|c|c|}
\hline & \multicolumn{6}{|c|}{$\mathrm{CO} 2$ emissions for heating/cooling $\left(\mathrm{CO}_{2} \mathrm{~kg} / \mathrm{m}^{2} /\right.$ year $)$ and reduction rates compared to $1990 \mathrm{~s}$ base model (\%) } \\
\hline & \multirow{2}{*}{$\begin{array}{l}\text { 1990s base model } \\
\left(0.376 \mathrm{CO}_{2} \mathrm{~kg} / \mathrm{kWh}\right)\end{array}$} & \multirow{2}{*}{$\begin{array}{c}\text { 1990s improved model } \\
\left(0.376 \mathrm{CO}_{2} \mathrm{~kg} / \mathrm{kWh}\right)\end{array}$} & \multicolumn{2}{|c|}{ 2040s improved model } & \multicolumn{2}{|c|}{ 2090s improved model } \\
\hline & & & $\left(0.551 \mathrm{CO}_{2} \mathrm{~kg} / \mathrm{kWh}\right)$ & $\left(0.689 \mathrm{CO}_{2} \mathrm{~kg} / \mathrm{kWh}\right)$ & $\left(0.551 \mathrm{CO}_{2} \mathrm{~kg} / \mathrm{kWh}\right)$ & $\left(0.689 \mathrm{CO}_{2} \mathrm{~kg} / \mathrm{kWh}\right)$ \\
\hline Sapporo & 10.2 & $6.7(-34.7 \%)$ & $4.3(-57.8 \%)$ & $5.4(-47.3 \%)$ & $4.0(-60.7 \%)$ & $5.0(-50.9 \%)$ \\
\hline Tokyo & 10.7 & $4.4(-58.6 \%)$ & $3.4(-68.0 \%)$ & $4.3(-60.0 \%)$ & $4.1(-61.9 \%)$ & $5.1(-52.3 \%)$ \\
\hline Naha & 18.7 & $9.3(-50.2 \%)$ & $7.7(-59.1 \%)$ & $9.6(-48.8 \%)$ & $8.8(-53.0 \%)$ & $11.0(-41.2 \%)$ \\
\hline
\end{tabular}

\subsection{Economic Analysis}

First, in order to analyse the cost effectiveness of each strategy, the expected additional costs to install the strategies was calculated in Table 13.

The additional costs for glazing/insulation improvements and overhangs were divided by their estimated life (20 years) to calculate the annual additional costs for convenience's sake, though originally the initial capital costs would all be in year zero. Additionally, the time value of money was not considered, since in Japan Overnight Call Rate Target (corresponding to the Current Bank Rate of the UK) and Consumer Price Index (CPI) have both been approximately zero $(26,27)$.

The additional costs for lighting and equipment improvements were estimated to be zero since this strategy comes mainly from technological progress by manufacturers, and so changes in the price were ignored in this study. The additional costs for relaxing temperature settings and for night cooling were also estimated to be zero, using existing Building Energy Management Systems.

Figure 5 and Table 13 indicate that the effect from overhangs on energy savings is limited and that this strategy is not effective compared to the costs incurred. As a result, in this economic analysis, the effect from overhangs for reducing cooling/heating loads was ignored and it was assumed that all overhangs were excluded. 
Table 13: Annual additional costs for the effective strategies for a single building.

\begin{tabular}{l|c|c|c|}
\hline & $\begin{array}{c}\text { Additional costs (A) } \\
(\mathrm{JPY})\end{array}$ & $\begin{array}{c}\text { The life (B) } \\
\text { (year) }\end{array}$ & $\begin{array}{c}\text { Annual additional costs (A/B) } \\
\text { (JPY/year) }\end{array}$ \\
\hline Lighting and equipment improvements & - & - & - \\
\hline Relaxation of the indoor air quality target & - & - & - \\
\hline $\begin{array}{l}\text { Double glazing with low-e coating \& } \\
\text { quadrupled insulation in the roof and external walls }\end{array}$ & $14.0 \mathrm{M}$ & 20 & $0.7 \mathrm{M}$ \\
\hline Overhangs & $27.3 \mathrm{M}$ & 20 & $1.4 \mathrm{M}$ \\
\hline Night cooling & - & - & - \\
\hline Total & & & $2.1 \mathrm{M}$ \\
\hline Total (excluding overhangs) & & & $0.7 \mathrm{M}^{*}$ \\
\hline
\end{tabular}

Next, the cost effectiveness for reducing electricity consumption with the effective strategies was examined in Table 14. It is clear from the table that the electricity rate is much higher than the expected costs from reducing electricity usage, demonstrating saving energy is the more cost effective strategy.

It is also clear that the expected costs for the effective strategies could be competitive with the nuclear power generating costs. Since nuclear power does not emit $\mathrm{CO} 2$ in the process of generating power (3), both of these are considered to be measures to reduce $\mathrm{CO} 2$ emissions effectively. It is important to note that nuclear power generating costs are the minimum and it is highly likely that the costs will be more expensive (28).

Overall, the costs for reducing heating/cooling loads in office buildings could be lower than not only the electricity rate but also that for nuclear power generation. 
Table 14: Cost comparison between electricity consumption reductions by the effective strategies and electricity rate and nuclear power generation $(28,29)$.

\begin{tabular}{|l|c|c|c|c|c|c|}
\hline \multicolumn{3}{|c|}{$\begin{array}{l}\text { Cost effectiveness for electricity consumption } \\
\text { reduction by effective strategies (JPY/ } / \mathbf{k W h})\end{array}$} & \multicolumn{2}{|c|}{ Electricity rate (JPY/kWh) } & $\begin{array}{c}\text { Minimam nuclear } \\
\text { power generating } \\
\text { cost (JPY/kWh) }\end{array}$ \\
\hline Sapporo & $1990 \mathrm{~s}$ & $2040 \mathrm{~s}$ & $2090 \mathrm{~s}$ & $\begin{array}{c}\text { Industrial, business use } \\
\text { (high tension voltage) }\end{array}$ & $\begin{array}{c}\text { Home usage } \\
\text { (low tension voltage) }\end{array}$ & \\
\hline Tokyo & 14.5 & 7.1 & 6.9 & & 27.7 & $10.3^{*}$ \\
\hline Naha & 8.2 & 6.1 & 6.5 & 19.4 & \\
\hline
\end{tabular}

${ }^{*} 0.057$ GBP

\section{CONCLUSIONS}

The potential impacts of climate change on the cooling and heating energy requirements for offices were investigated by means of thermal analysis simulations and hourly reference weather years over three periods; 1981-2000 (1990s), 2031-2050 (2040s), and 2081-2100 (2090s). A case study, multi-storey office building was tested in three different Japanese locations. A series of different energy saving measures were tested including: improved building envelope components, reduced internal heat gains, relaxed targets for indoor air quality, a fixed infiltration rate, and a fixed window area fraction of $30 \%$. This study quantified how such measures could have a direct effect on the total heating/cooling loads in both current and future offices. It also revealed that under the IPCC's A2 carbon emission scenario, substantial reductions of energy consumption are expected in all locations over all periods if the full range of measures and technologies that are currently available, were to be implemented, while bearing in mind that other types of buildings and other climate change scenarios might react differently to changing conditions. However, the reduction rates can change significantly in each location and each period due to regional climate characteristics and climate change. In the future, cooling loads will increase and heating loads will decrease due to higher external temperatures. As a result, in the future in Sapporo the total energy requirements for heating/cooling will be almost constant, while a distinct increasing trend could potentially be observed for both Tokyo and Naha, which are locations where cooling is dominant.

Additionally, sufficient reductions in the heating/cooling loads and energy consumption do not necessarily mean that the $\mathrm{CO} 2$ emissions reduction targets set by the Japanese government will be achieved. This is because electricity conversion factors could worsen due to revisions of the national energy plan triggered by the Fukushima nuclear accident aiming to reduce dependency on nuclear power. Thus, in order to attain the national target, further energy reduction measures, on both the supply and demand sides, should be considered. What is particularly important is decarbonising the grid. The findings of this study would help building designers, 
engineers, urban planners, energy and environmental policy makers, utilities, and other stakeholders to consider the impact of climate change on energy production, distribution, and consumption. They have traditionally assumed an unchanging external climate. Confronted with climate change, this approach should be revised and necessary measures must be taken.

As a result, more attention should be paid to the regional and global impact of climate change of building energy codes. For example, the standards for office heating/cooling loads in perimeter zones could vary by location, and could more closely reflect the total load increases in the future. Moreover, efficient building envelopes, as well as lighting, appliances, and HVAC systems with higher efficiency would need to be developed. A series of more efficient strategies (e.g. heat recovery, triple glazing with argon gas) could be simulated to determine the increased efficiency needed to compensate for the heating/cooling demand increases from climate change. Furthermore, some supports, policy implications, suitable suggestions, and political and awareness-raising activities should be proposed for end-users in order to change their activities, such as by relaxing the indoor air quality targets.

Around one-third of the office building stock in the chief cities of Japan dates from before 1981 (13). This means that Japan still has a vast quantity of old offices without sufficiently effective energy measures. The measures introduced in this study are typical, popular, and not very specific and could lead to significant reductions in energy consumption. With more specific and modern technologies, even greater energy reductions could be completed more effectively and efficiently. A brief economic analysis suggested that these measures could be competitive with nuclear power generation, especially in the future.

In conclusion, office buildings in Japan have enormous potential to reduce energy requirements and related CO2 emissions without resorting to nuclear power generation.

\section{ACKNOWLEDGMENTS}

The authors would like to thank Assoc. Prof. Kazuhiro Soga at the Graduate School of Science and Engineering, Kagoshima University in Japan, who provided useful weather files and resources.

\section{REFERENCES}

(1) Ministry of Education, Culture, Sports, Science and Technology (MEXT), Japan Meteorological Agency (JMA), Ministry of the Environment (MOE). 2009. Synthesis report on observations, projections, and impact assessments of climate change, climate change and its impacts in Japan [online].

(2) “ 2050 Japan Low-Carbon Society” scenario team. 2008. Japan Scenarios and Actions towards Low-Carbon Societies (LCSs) [online].

http://2050.nies.go.jp/report/file/lcs_japan/2050_LCS_Scenarios_Actions_English_080715.pdf. [Accessed Oct 2015]. 
http://www.env.go.jp/en/earth/cc/report_impacts.pdf. [Accessed Oct 2015].

(3) Agency for Natural Resources and Energy (ANRE). 2014. Energy in Japan 2014 [online]. http://www.enecho.meti.go.jp/about/whitepaper/2014html/ [Accessed Jan 2015] [in Japanese].

(4) Energy Conservation Center, Japan (ECCJ). 2014. Japan energy conservation handbook 2013 [online]. http://www.asiaeec-col.eccj.or.jp/databook/2013/handbook13.pdf. [Accessed Aug 2015].

(5) Ministry of Economy, Trade and Industry. 2014. Strategic Energy Plan [online]. http://www.enecho.meti.go.jp/en/category/others/basic_plan/pdf/4th_strategic energy plan.pdf. [Accessed August 2015].

(6) Soga K, Akasaka H. 2004. Study on the method for constructing a reference weather year, A comparison of the EA method and the SHASE method. Journal of Environmental Engineering (Transactions of AIJ) Vol.581, 21-28 [in Japanese].

(7) Kubota M, Soga K. 2010. Study on future weather data considering effect of global warming; Part 3 Verification of prediction value of solar irradiance and wind velocity, and Improvement on synthetic method of future weather data. AIJ Kyushu Chapter Architectural Research Meeting (Environment) Vol.49, 149-152 [in Japanese].

(8) Thermal Analysis Software (TAS). Available from: http://www.edsl.net/main/Software.aspx.

(9) Akasaka H, Nimiya H, Matsumoto S, Miki N, Emura K, Emura E, Takemasa K. 2003. Expanded AMeDAS weather data. Tokyo: Architectural Institute of Japan (AIJ).

(10) Japan Meteorological Agency (JMA). 2005. Global warming projection bulletin, Vol. 6 [online]. http://ds.data.jma.go.jp/tcc/tcc/products/gwp/gwp6/index.html. [Accessed Oct 2015]

(11) Soga K. 2011. Development of future weather data based on climate change scenario. Summaries of Technical Papers of Annual Meeting (Kanto), Architectural Institute of Japan (AIJ), 467-468 [in Japanese].

(12) Takizawa H. 1985. Proposal of standard problem (Standard problem for office buildings). The 15th symposium on heat, Architectural Institute of Japan [in Japanese].

(13) Japan Real Estate Institute (JREI). 2014. The annual Japanese office Buildings survey (9 $9^{\text {th }}$ of Oct. 2014) [online]. http://www.reinet.or.jp/?p=13875. [Accessed Aug 2015] [in Japanese]

(14) Mingfang T. 2002. Solar control for buildings. Building and Environment Vol.37, 659-664

(15) Ministry of the Environment. 2013. Japan Environment Quarterly (JEQ) Volume 3 October 2013, Climate Change Policies in Japan / What are COOL BIZ and WARM BIZ? [online]. http://www.env.go.jp/en/focus/jeq/issue/vol03/feature.html. [Accessed Aug 2015] [in Japanese]. (16) Pacheco R, Ordonez J, Martinez G. 2012. Energy efficient design of building: A review. Renewable and Sustainable Energy Reviews Vol.16, No.6, 3559-3573 
(17) Yang A, Li HX, Hu YF. 2006. Study on solar radiation and energy efficiency of building glass system. Applied Thermal Engineering Vol.26, No.8-9, 956-961

(18) Bauchlaghem N. 2000. Optimising the design of building envelopes for thermal performance. Automation in Construction Vol.10, No.1, 101-112

(19) Kolokotroni M, Ren X, Davies M, Mavrogianni A. 2011. London's urban heat island: Impact on current and future energy consumption in office buildings. Energy and Buildings Vol.47, 302-311

(20) Kokuryo T, Soga K, Kubota M, Harada Y. 2010. Projection of the influence of climate change on airconditioning load: Part 2 Comparison on long term variation of air-conditioning load in Sapporo, Tokyo and Naha. Summaries of Technical Papers of Annual Meeting (Hokuriku), Architectural Institute of Japan (AIJ), 507-508 [in Japanese].

(21) Kubota M, Soga K, Kokuryo T, Harada Y. 2010. Projection of the influence of climate change on airconditioning load: Part 1 Case study on year to year change of air-conditioning load for 200 years in Tokyo.

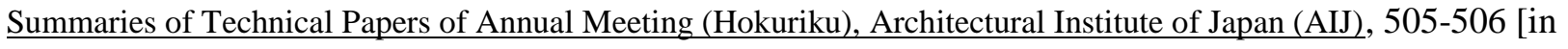
Japanese].

(22) Advisory Committee on Energy and Natural Resources (ACENR). 2007. The present situation of airconditioning (Energy efficiency and conservation subcommittee) [online].

http://www.meti.go.jp/committee/materials/downloadfiles/g70622b05j.pdf. [Accessed August 2015] [in Japanese].

(23) Advisory Committee on Energy and Natural Resources (ACENR). 2009. Final report (Energy efficiency and conservation subcommittee) [online]. http://www.meti.go.jp/committee/materials/downloadfiles/g80222b02j.pdf. [Accessed Oct 2015] [in Japanese].

(24) Federation of Electric Power Companies of Japan (FEPC). 2011. Global warming counter measures of electric power industries [online]. http://www.meti.go.jp/committee/summary/0004606/2011_04_01.pdf. [Accessed Oct 2015] [in Japanese].

(25) Agency for Natural Resources and Energy (ANRE). 2015. Calculation and announcement of carbon dioxide emission factor by electric power supplier [online].

http://www.enecho.meti.go.jp/category/electricity_and_gas/electric/gwc/pdf/tutatu.pdf. [Accessed Oct 2015] [in Japanese].

(26) Gaitame.Com Co.,Ltd. 2015. Trends in O/N Call Rate Target [online]. http://www.gaitame.com/market/japan.html. [Accessed August 2015] [in Japanese]. (27) Ministry of Internal Affairs and Communications (MIC). 2015. Time series data of CPI (Statistics bureau, director-general for policy planning (statistical standards) and statistical research and training institute) [online]. http://www.stat.go.jp/data/cpi/historic.htm. [Accessed Aug 2015] [in Japanese]. 
(28) Energy and Environment Council (EEC). 2015. Report of inspection of the generation cost for long-term energy supply-demand forecasts subcommittee [online].

http://www.enecho.meti.go.jp/committee/council/basic_policy_subcommittee/mitoshi/cost_wg/007/pdf/007_05. pdf. [Accessed Aug 2015] [in Japanese].

(29) Agency for Natural Resources and Energy (ANRE). 2012. International comparison of electricity rate [online]. http://www.enecho.meti.go.jp/about/whitepaper/2014html/2-2-4.html. [Accessed Aug 2015] [in Japanese].

(30) Construction Research Institute. 2015. Kensetsu bukka, 2015-9 (1168): 16-19, 86-89, 471-475, 482-483, 689-695, 867 [in Japanese].

(31) Construction Research Institute. 2015. Kenchiku cost jyouhou, 2015-10 autumn (67): 304-305, 318-319 [in Japanese].

(32) Sugita Ace Co.,Ltd. 2015. Catalog 2015, https://service.sugita-ace.co.jp/productssearch/. [Accessed Oct 2015] [in Japanese].

\section{APPENDIX}

Appendix 1 Target temperature and relative humidity for the base model for typical 1990s type office buildings (12)

\begin{tabular}{|c|c|c|c|}
\hline \multicolumn{2}{|c|}{ Season } & Temperature $\left({ }^{\circ} \mathrm{C}\right)$ & $\mathrm{RH}(\%)$ \\
\hline Winter & $($ Jan-Apr + Dec) & $21-24$ & $40-60$ \\
\hline Summer & (Jun-Sep) & $23-26$ & $45-65$ \\
\hline Mid season & (Other) & $21-25$ & $40-65$ \\
\hline
\end{tabular}

Appendix 2 Definition of non-working day and working day for typical 1990s type office buildings

\begin{tabular}{|c|c|c|}
\hline \multirow[b]{2}{*}{$\begin{array}{l}\text { Non-working } \\
\text { day }\end{array}$} & Weekend & Sunday, Saturday \\
\hline & Holiday & $\begin{array}{l}\text { 1-3 Jan, } 15 \text { Jun, } 11 \text { Feb, } 20 \text { Mar, } 29 \text { Apr, 3-5 May, } 20 \text { Jul, } \\
17 \text { Sep, } 24 \text { Sep, } 8 \text { Oct, } 3 \text { Nov, } 23 \text { Nov, } 23 \text { Dec, } 29-31 \text { Dec, } \\
\text { Monday make up holiday (when holidays fall on Sunday) }\end{array}$ \\
\hline Working day & Weekday & Other (9.00 AM-18.00 PM) \\
\hline
\end{tabular}


Appendix 3 Estimated costs for each strategy $(30,31,32)$

\begin{tabular}{|c|c|c|c|c|}
\hline \multicolumn{5}{|l|}{ Glazing* } \\
\hline & Unit price $(A)$ & Quantity (B) & Total price $(A \times B)$ & Reference \\
\hline Single clear glazing $(\mathrm{C})$ & 35,380 (JPY/unit) & 256 (unit) & $9,057,280(J P Y)$ & \multirow{2}{*}{50,51} \\
\hline Double glazing with low-e (D) & 57,750 (JPY/unit) & 256 (unit) & 14,784,000 (JPY) & \\
\hline \multicolumn{3}{|l|}{ Additional costs (C-D) } & $\begin{array}{c}5,726,720 \text { (JPY) } \\
(31,497 \text { (GBP)) }\end{array}$ & \\
\hline \multicolumn{5}{|l|}{ Insulation** } \\
\hline & Unit price $(A)$ & Quantity (B) & Total price $(A \times B)$ & Reference \\
\hline Thickness 25 mm (C) & $661\left(\mathrm{JPY} / \mathrm{m}^{2}\right)$ & $4,202\left(\mathrm{~m}^{2}\right)$ & 2,777,522 (JPY) & \multirow{2}{*}{50} \\
\hline Thickness 100 mm (D) & 2,640 (JPY/m²) & $4,202\left(\mathrm{~m}^{2}\right)$ & 11,093,280 (JPY) & \\
\hline \multicolumn{3}{|l|}{ Additional costs (C-D) } & $\begin{array}{c}8,315,758 \text { (JPY) } \\
(45,736(\mathrm{GBP}))\end{array}$ & \\
\hline \multicolumn{5}{|l|}{ Overhang } \\
\hline & Unit price $(A)$ & Quantity (B) & Total price $(A \times B)$ & Reference \\
\hline Material costs $(C)$ & 248,000 (JPY/unit) & 108 (unit) & 26,784,000 (JPY) & 52 \\
\hline Construction costs (D) & 23,100 (JPY/person/day) & 24 (person $\times$ day) & 554,400 (JPY) & 50 \\
\hline \multicolumn{3}{|l|}{ Additional costs $(C+D)$} & $\begin{array}{c}27,338,400 \text { (JPY) } \\
(150,360 \text { (GBP)) }\end{array}$ & \\
\hline \multicolumn{5}{|c|}{ * Difference between construction costs for single glazing and double glazing with low-e was estimated to be 0 . } \\
\hline \multicolumn{5}{|c|}{ ** Difference between construction costs for $25 \mathrm{~mm}$ insulation and $100 \mathrm{~mm}$ insulation was estimated to be 0 . } \\
\hline
\end{tabular}

